\title{
ANALISIS FAKTOR-FAKTOR PENYEBAB SISA MAKANAN CAIR PASIEN KELAS 2 DAN 3 DI GEDUNG A RSUPN DR. CIPTO MANGUNKUSUMO JAKARTA TAHUN 2019
}

\author{
The Analysis of Factors Causing Liquid Diet Waste of Patient Class 2 and 3 at A Building \\ RSUPN Dr. Cipto Mangunkusumo Jakarta Tahun 2019
}

\author{
Abidah Syauqiyatullah ${ }^{1}$, Irfanny Z. Anwar ${ }^{1}$, Ferina Darmarini' ${ }^{2}$, Ahmad Syauqy ${ }^{3}$ \\ ${ }^{1}$ Politeknik Kesehatan Kemenkes Jakarta 2 \\ 2 Intalasi Gizi RSUPN Dr. Cipto Mangunkusumo \\ ${ }^{3}$ Departemen IImu Gizi, Fakultas Kedokteran, Universitas Diponegoro \\ E-mail: irfannyafif@gmail.com
}

\begin{abstract}
Plate waste is one of the indicators of minimum standard nutrition service at a hospital. Several studies at RSUPN Dr. Cipto Mangunkusumo Jakarta showed that plate waste which higher than the standard still existed. Nevertheless, no research has been done to clarify factors causing a liquid diet. This research aims for finding out the analysis of factors causing liquid diet waste of patient classes 2 and 3 at $A$ Building RSUPN Dr. Cipto Mangunkusumo Jakarta. It was conducted in April 2019 using a cross-sectional design and accidental sampling. The liquid diet waste was acquired by the food weighing method. A questionnaire was used to collect data. The result showed that the liquid diet waste in category $>\mathbf{2 0} \%$ reached 88,7 percent. The results of statistical analysis explained that there were no significant relations between gender, age, education, information and education of nutrition, patient's clinical obstacles, and food and diet obstacles with liquid diet waste. However, there were tendencies to leave liquid diet on male patients, patients with the age of $\geq 35$ years old, patients with higher education degrees, patients who did not receive information and education of nutrition, and patients with other obstacles. Therefore, the hospital and nutrition installation need to evaluate the acceptability of a liquid diet so it can increase patients' intake of a liquid diet.
\end{abstract}

Keywords: liquid diet waste, information and education of nutrition, patients

\section{ABSTRAK}

Sisa makanan merupakan salah satu indikator standar pelayanan minimal gizi rumah sakit. Dari beberapa penelitian di RSUPN Dr. Cipto Mangkusumo Jakarta, masih terdapat sisa makanan yang melebihi standar pelayanan minimal gizi rumah sakit tetapi penelitian mengenai sisa makanan cair belum pernah dilakukan sebelumnya. Penelitian ini bertujuan untuk menganalisis faktor-faktor penyebab sisa makanan cair pasien kelas 2 dan 3 di Gedung A RSUPN Dr. Cipto Mangunkusumo. Penelitian dilakukan pada bulan April 2019 dengan desain cross-sectional dan metode pemilihan sampel accidental sampling. Pemberian kuesioner kepada pasien dilakukan untuk mengetahui pemberian informasi dan edukasi gizi dan kendala yang dihadapi pasien dalam mengonsumsi makanan cair sedangkan data sisa makanan diperoleh dengan cara penimbangan. Berdasarkan hasil analisis univariat diketahui bahwa distribusi frekuensi sisa makanan cair dalam kategori tidak terpenuhi (>20\%) mencapai 88,7 persen. Sisa makanan cair diketahui tidak memiliki hubungan yang signifikan terhadap jenis kelamin, kelompok umur, tingkat pendidikan, dan pemberian informasi dan edukasi gizi, kendala klinis dan kendala makanan dan menu yang dihadapi pasien. Namun, terdapat kecenderungan lebih banyak terjadinya sisa makanan cair pada pasien berjenis kelamin laki-laki, pasien berumur $\geq 35$ tahun, pasien dengan tingkat pendidikan minimal SMA, pasien yang tidak diberikan informasi dan edukasi gizi, dan pasien dengan kendala lain-lain. Oleh karena itu, pihak rumah sakit khususnya instalasi gizi, perlu mengevaluasi lebih lanjut kepuasan pasien terhadap makanan cair sehingga dapat dijadikan masukan dalam meningkatkan asupan makanan cair.

Kata kunci: sisa makanan cair, informasi dan edukasi gizi, pasien

Doi: 10.36457/gizindo.v43i2.472

www.persagi.org/ejournal/index.php/Gizi_Indon 


\section{PENDAHULUAN}

$\mathrm{P}$ elayanan Gizi Rumah Sakit sebagai bagian integral dari pelayanan kesehatan yang menyeluruh di rumah sakit merupakan salah satu upaya dalam rangka meningkatkan kualitas pelayanan kesehatan bagi pasien rawat inap maupun pasien rawat jalan di rumah sakit. Dikatakan bermutu jika memenuhi 3 komponen mutu pelayanan gizi, yaitu: 1.) pengawasan dan pengendalian mutu dalam menjamin produk yang dihasilkan aman, 2.) menjamin kepuasan konsumen, dan 3.) assessment yang berkualitas. Hal ini sejalan dengan indikator Standar Pelayanan Gizi sebagai Standar Pelayanan Minimal Rumah Sakit meliputi ketepatan waktu pemberian makanan kepada pasien (100\%), sisa makanan yang tidak dihabiskan oleh pasien $(\leq 20 \%)$ dan tidak ada kesalahan pemberian $\operatorname{diet}(100 \%)$. ${ }^{1}$

Mutu pelayanan rumah sakit yang belum terlaksana dengan maksimal akan berpengaruh kurang baik terhadap mutu makanan yang disajikan. Akibatnya pasien meninggalkan banyak sisa makanannya. ${ }^{2}$ Sisa makanan merupakan jumlah makanan yang masih tertinggal di alat hidang ketika pasien selesai makan. ${ }^{3}$ Sisa makanan dipengaruhi oleh faktor internal, eksternal dan lingkungan pasien. ${ }^{3}$ Faktor internal termasuk dalam faktor yang berasal dari dalam diri pasien sendiri, seperti keadaan psikis, fisik, dan kebiasaan makan. Faktor eksternal adalah faktor yang berasal dari luar diri pasien, meliputi penampilan makanan dan rasa makanan. Faktor terakhir, yaitu faktor lingkungan, termasuk jadwal/waktu pemberian makanan, makanan dari luar rumah sakit, alat makan dan keramahan penyaj/pramusaji makanan. ${ }^{4}$

Standar Pelayanan Minimal Rumah Sakit di bidang gizi yang diatur dalam Menteri Kesehatan Republik Indonesia Nomor 129/Menkes/SK/II/2008 menyebutkan bahwa sisa makanan masih bisa ditoleransi apabila memenuhi standar sebesar $\leq 20$ persen. ${ }^{5}$ Berbagai metode untuk menghitung sisa makanan banyak digunakan tetapi metode penimbangan makanan merupakan metode paling tepat untuk memperkirakan makanan dan atau asupan zat gizi untuk individu. ${ }^{4}$ Presentase sisa makanan dihitung dengan cara membandingkan sisa makanan dengan standar porsi makanan rumah sakit kemudian dikalikan 100 persen.

Beberapa penelitian yang dilakukan di rumah sakit (RS) di Indonesia menunjukkan data yang bervariasi dalam konteks sisa makanan. Penelitian di RS Prirngadi Medan oleh Elsa Sembiring pada tahun 2014 didapatkan data sisa makanan biasa sebesar 32,92 persen. ${ }^{6}$ Di RSUD Dr. H. Moch Ansari Saleh Banjarmasin, pada tahun 2014 Salman dkk., menemukan rata-rata sisa makanan pasien bersisa banyak (>25\%) pada jenis makanan lauk nabati sebesar 55,6 persen dan lauk hewani sebesar 51,1 persen. ${ }^{7}$ Sedangkan, dalam penelitian yang dilakukan oleh Yahya Nashua pada tahun 2018 di RS Bhakti Asih Brebes, sisa makanan lauk nabati sebesar 39,61 persen. ${ }^{8}$ Sisa makanan paling banyak pada makan siang pasien Diabetes Mellitus di RSI Klaten tahun 2007 adalah pada makanan pokok sebesar 86,21 persen. ${ }^{9}$

Penelitian dengan metode quasi eksperimen oleh Anna Ngatmira di RSUPN Dr. Cipto Mangunkusumo pada tahun 2013 didapatkan bahwa sisa makanan biasa terbesar disumbangkan dari makanan pokok $(41,52 \%$ pada kelompok kontrol dan $32,87 \%$ pada kelompok perlakuan). ${ }^{10}$ Berbagai faktor seperti faktor internal, eksternal, dan lingkungan menyebabkan terjadinya sisa makanan dalam porsi besar. Faktor internal pasien didominasi oleh kondisi fisik, kebiasaan makan, dan perbedaan jenis kelamin. Faktor eksternal pasien didominasi oleh rasa makanan, penampilan makanan, dan kurangnya variasi makanan. Faktor lingkungan yang didominasi oleh peranan keluarga yang memberi-kan makanan luar rumah sakit, membantu dan memberi motivasi pasien. ${ }^{11}$

Meskipun demikian, penelitian tentang sisa makanan cair masih jarang dilakukan. Makanan cair adalah makanan berkonsistensi cair hingga kental yang diberikan kepada pasien yang mengalami ganguan mengunyah, menelan, dan mencernakan makanan karena menurunnya kesadaran, suhu tinggi, rasa mual, muntah, pasca pendarahan saluran cerna, serta pra dan pascabedah. Makanan dapat diberikan secara oral atau peroral. Menurut konsistensinya, terdapat tiga jenis makanan cair, yaitu makanan cair jernih, makanan cair penuh, dan makanan cair kental. ${ }^{12}$

Pemilihan lokasi penelitian di RSUPN Cipto Mangunkusumo didasarkan atas observasi 
Dietisien RSUPN Cipto Mangunkusumo yang menunjukkan hasil bahwa banyak sisa makanan cair di Unit Rawat Inap Gedung A yang belum diketahui penyebabnya. Selain itu, belum pernah dilakukan penelitian mengenai sisa makanan cair pada pasien kelas 2 dan 3 di Unit Rawat Inap Terpadu Gedung A.

Perumusan masalah dalam penelitian ini adalah mencari tahu faktor-faktor penyebab sisa makanan cair pasien kelas 2 dan 3 di Gedung A RSUPN Dr. Cipto Mangunkusumo. Penelitian ini bertujuan untuk menganalisis faktori-faktor penyebab terjadinya sisa makanan cair pasien kelas 2 dan 3 di Gedung A di RSUPN Dr Cipto Mangunkusumo. Adapun manfaat dari penelitian ini bagi rumah sakit adalah sebagai masukan dan informasi dalam pemecahan masalah yang berkaitan dengan penyebab sisa makanan cair. Selain itu, penelitian ini juga bermanfaat untuk meningkatkan kualitas penyelenggaraan makanan di RSUPN Dr. Cipto Mangunkusumo sebagai bagian dari pelayanan gizi di rumah sakit.

\section{METODE PENELITIAN}

Penelitian ini termasuk dalam ruang lingkup gizi institusi. Penelitian kuantitatif dengan metode deskriptif-analitik dan rancangan crosssectional. Populasi adalah pasien berumur 18 tahun ke atas yang dirawat inap di kelas 2 dan 3 di Gedung A RSUPN Dr. Cipto Mangunkusumo dan menerima diet makanan cair dengan jumlah total populasi 71 orang yang terdiri dari 30 lakilaki dan 41 perempuan. Responden tertua berumur 77 tahun.

Pengambilan sampel dalam penelitian ini menggunakan teknik accidental sampling yang dibatasi dalam waktu 4 hari karena dalam jangka waktu tersebut jumlah responden sudah memenuhi, yaitu 71 orang. Sampel diperoleh dari populasi yang memenuhi kriteria inklusi, yaitu pasien kelas 2 dan 3 yang dirawat di Gedung A dengan umur minimal 18 tahun yang menerima makanan cair melalui jalur oral dan NGT lalu menyisakan makanan cair untuk pertama kali selama waktu pengambilan data dan komunikatif. Kriteria eksklusi adalah pasien kelas 2 dan 3 di Gedung A yang mengundurkan diri selama penelitian berlangsung. Didapatkan 71 responden yang terdiri dari 30 laki-laki dan 41 perempuan yang memenuhi kriteria inklusi selama 4 hari penelitian.
Pengumpulan data dibantu oleh enumerator yang terdiri dari 9 orang mahasiswa Jurusan Gizi Poltekkes Jakarta II yang dibagi menjadi dua kelompok, yaitu enumerator penimbang dan enumerator pewawancara. Enumerator penimbang bertugas memisahkan botol makanan cair yang bersisa, menimbang sisa makanan cair, dan melakukan pencatatan dan dokumentasi. Enumerator pewawancara bertugas mengunjungi pasien, membacakan informed consent, melakukan wawancara dengan menggunakan kuesioner mengenai edukasi dan konseling gizi dan kendala yang dihadapi pasien dalam mengonsumsi makanan cair, serta melakukan pencatatan dari rekam medik pasien. Sebelumnya, telah dilakukan diskusi dan penyamaan persepsi antara peneliti dan enumerator tentang cara pengambilan data. Wawancara dilakukan pada hari pertama subjek dipilih. Pengambilan data sisa makanan dilakukan setiap kali selesai pemberian makanan cair selama 4 hari berturut-turut.

Variable bebas berupa data primer yang meliputi jenis kelamin, umur, tingkat pendidikan, departemen perawatan, pemberian informasi dan edukasi gizi, serta kendala yang dihadapi pasien. Variable terikat adalah sisa makanan cair yang diperoleh dengan cara penimbangan.

Pengolahan dan analisis data menggunakan program aplikasi komputer. Analisis univariat dilakukan untuk melihat gambaran karakteristik subjek (jenis kelamin, umur, tingkat pendidikan, dan departemen perawatan) sisa makanan cair, jalur pemberian makanan cair, jenis sisa makanan cair, pemberian informasi dan edukasi gizi, serta kendala yang dihadapi pasien. Analisis bivariat menggunakan uji Chi-square dan apabila tidak terpenuhi digunakan uji Fisher's Exact dengan tingkat kepercayaan $95 \%$ dan nilai $p<0,05$. Data disajikan dalam bentuk tabel.

Kategori jenis kelamin dibagi menjadi lakilaki dan perempuan. Kategori umur dibagi menjadi dua, yaitu $<35$ tahun dan $\geq 35$ tahun. Tingkat pendidikan dibagi menjadi dua kategori, Dasar (<SMA) dan Lanjut ( $\geq S M A)$. Departemen perawatan dibagi menjadi lima departemen, yaitu Departemen Obsgin dan Kebidanan, Departemen Bedah, Departemen Stroke dan Kulit Kelamin, Departemen Penyakit Dalam, dan Departemen Geriatri. Sisa makanan cair terkategori rendah apabila mencapai $\leq 20$ persen, terkategori tinggi apabila $>20$ persen. 
Jenis sisa makanan dibagi menjadi enam kategori, Low Lactose Milk (LLM), Blenderize, Cair DM, Cair TPS, Cair Jernih, dan Cair Komersil. Jalur pemberian makanan cair dibagi menjadi oral dan selang. Pemberian informasi dan edukasi gizi terkategori diberikan apabila pasien dan/atau pihak keluarga merasa pernah mendapat pemberian informasi dan edukasi gizi dan terkategori tidak diberikan apabila merasa tidak pernah mendapat. Kendala klinis yang merupakan masalah yang berhubungan dengan keadaan fisik dan klinis pasien terkategori banyak apabila memiliki $\geq 2$ kendala dan terkategori sedikit apabila memiliki $<2$ kendala. Kendala makanan dan menu yang memiliki pengertian masalah pada hidangan yang disajikan yang dirasakan pasien terkategori ada apabila subjek memiliki kendala makanan dan menu dan terkategori tidak ada apabila tidak memiliki kendala makanan dan menu. Kendala lain-lain dengan arti masalah lainnya yang dihadapi pasien terkategori ada apabila subjek memiliki kendala lain-lain dan terkategori tidak ada apabila tidak memiliki kendala lain-lain.

Penelitian ini telah mendapat persetujuan dari komisi etik Fakultas Kedokteran Universitas Indonesia No. 0905/UN2.FI/ETIK/2018. Semua informasi dan data yang dikumpulkan dari subjek penelitian menggunakan informed consent dengan dijamin kerahasiaannya dan hanya digunakan untuk keperluan ilmiah.

\section{HASIL}

Karakteristik subjek disajikan dalam Tabel 1. Hasil pada Tabel 1 menunjukkan bahwa sebagian besar pasien berjenis kelamin perempuan, umur $\geq 35$ tahun, memiliki tingkat pendidikan minimal SMA. Distribusi kelas perawatan sebagian besar terdapat di bagian Penyakit Dalam. Sisa makanan cair, jenis sisa, dan jalur pemberian makanan cair disajikan dalam Tabel 2.

Dari Tabel 2 diketahui bahwa sebagian besar subjek (88.7\%) menyisakan makanan cair dalam kategori sisa makanan tinggi (>20\%). Jenis makanan cair yang sebagian besar disisakan adalah jenis Formula Rumah Sakit, Low Lactose Milk (LLM) $(47,9 \%)$ dan makanan cair yang paling sedikit disisakan adalah makanan cair komersil $(4,2 \%)$. Jalur pemberian makanan sebagian besar menggunakan jalur oral $(71,8 \%)$. Pemberian informasi dan edukasi gizi dan kendala yang dihadapi subjek disajikan dalam Tabel 3.

Tabel 1

Karakteristik Pasien Kelas 2 dan 3

\begin{tabular}{ccc}
\hline \multirow{2}{*}{ Karakteristik } & \multicolumn{2}{c}{ Jumlah } \\
\cline { 2 - 3 } Jenis kelamin & $\mathrm{n}$ & $\%$ \\
$-\quad$ Laki-laki & 30 & 42,3 \\
$-\quad$ Perempuan & 41 & 57,7 \\
Umur & & \\
$-\quad<35$ tahun & 16 & 22,6 \\
$-\quad \geq 35$ tahun & 55 & 77,4 \\
Tingkat Pendidikan & & \\
$-\quad$ Dasar (<SMA) & 22 & 30,9 \\
$-\quad$ Lanjut ( $\geq$ SMA) & 49 & 69,1 \\
Departemen Perawatan & & \\
$-\quad$ Obsgin dan Onkologi & 8 & 11,3 \\
$-\quad$ Bedah & 12 & 16,9 \\
$-\quad$ Stroke dan Kulit Kelamin & 13 & 18,3 \\
$-\quad$ Penyakit Dalam & 24 & 33,8 \\
$-\quad$ Geriatri & 14 & 19,7 \\
\hline
\end{tabular}


Tabel 2.

Sisa Makanan Cair, Jenis Sisa Makanan Cair, dan Jalur Pemberian Subjek

\begin{tabular}{ccc}
\hline \multirow{2}{*}{ Variabel } & \multicolumn{2}{c}{ Jumlah } \\
\cline { 2 - 3 } Sisa Makanan & $\mathrm{N}$ & $\%$ \\
- Rendah $(\leq 20 \%)$ & 8 & 11,3 \\
- Tinggi (>20\%) & 63 & 88,7 \\
Jenis Sisa Makanan & & \\
- Low Lactose Milk (LLM) & 34 & 47,9 \\
- Blenderize & 10 & 14,1 \\
- Cair DM & 8 & 11,3 \\
- Cair TPS & 4 & 5,6 \\
- Cair Jernih & 12 & 16,9 \\
- Cair Komersil & 3 & 4,2 \\
Jalur Pemberian Makanan Cair & & \\
- Oral & 51 & 71,8 \\
- Selang & 20 & 28,2 \\
\hline
\end{tabular}

Tabel 3

Pemberian Informasi dan Edukasi Gizi dan Kendala yang Dihadapi Subjek

\begin{tabular}{ccc}
\hline \multirow{2}{*}{ Variabel } & \multicolumn{2}{c}{ Jumlah } \\
\cline { 2 - 3 } & $\mathrm{n}$ & $\%$ \\
\hline Pemberian Informasi dan Edukasi Gizi & 51 & 71,8 \\
$-\quad$ Diberikan & 20 & 28,2 \\
$-\quad$ Tidak diberikan & & \\
Kendala yang Dihadapi Pasien & 56 & 78,9 \\
- Kendala klinis & 4 & 5,6 \\
$-\quad$ Kendala makanan dan menu & 11 & 15,5 \\
$-\quad$ Kendala lainnya & & \\
\hline
\end{tabular}

Dari Tabel 3 dapat diketahui bahwa subjek yang menerima informasi dan edukasi gizi sebesar 71,8 persen dan subjek yang tidak menerima informasi dan edukasi gizi sebanyak 28,2 persen. Oleh karena itu, dapat dikatakan bahwa sebagian besar subjek menerima informasi dan edukasi gizi. Kendala yang dihadapi pasien dalam mengonsumsi makanan cair disajikan dalam Tabel 6 .

Tabel 3 didapatkan bahwa terdapat tiga jenis kendala yang dihadapi pasien dalam mengonsumsi makanan cair. Kendala terbesar yang dihadapi pasien merupakan kendala klinis. Sementara Tabel 4 menyajikan gambaran karakteristik, pemberian informasi dan edukasi gizi, kendala yang dihadapi pasien tehadap sisa makanan cair. Dari Tabel 4 dapat diketahui bahwa proporsi sisa makanan kategori tinggi $(>20 \%)$ lebih banyak terjadi pada subjek yang berjenis kelamin laki-laki $(93,3 \%)$, subjek yang berusia $\geq 35$ tahun $(89,1 \%)$, subjek yang memiliki pendidikan lanjut $(89,8 \%)$, subjek yang di rawat di departemen stroke (100\%), subjek yang tidak menerima informasi dan edukasi gizi $(90 \%)$, subjek dengan kendala lain-lain,(100\%). Hasil analisis menunjukkan tidak terdapat hubungan secara statistik antara variabel bebas dengan variable terikat. Namun dapat diidentifikasi adanya kecenderungan sisa makanan. 
Tabel 4

Gambaran Karakteristik, Pemberian Informasi dan Edukasi Gizi, Kendala yang Dihadapi Pasien tehadap Sisa Makanan Cair

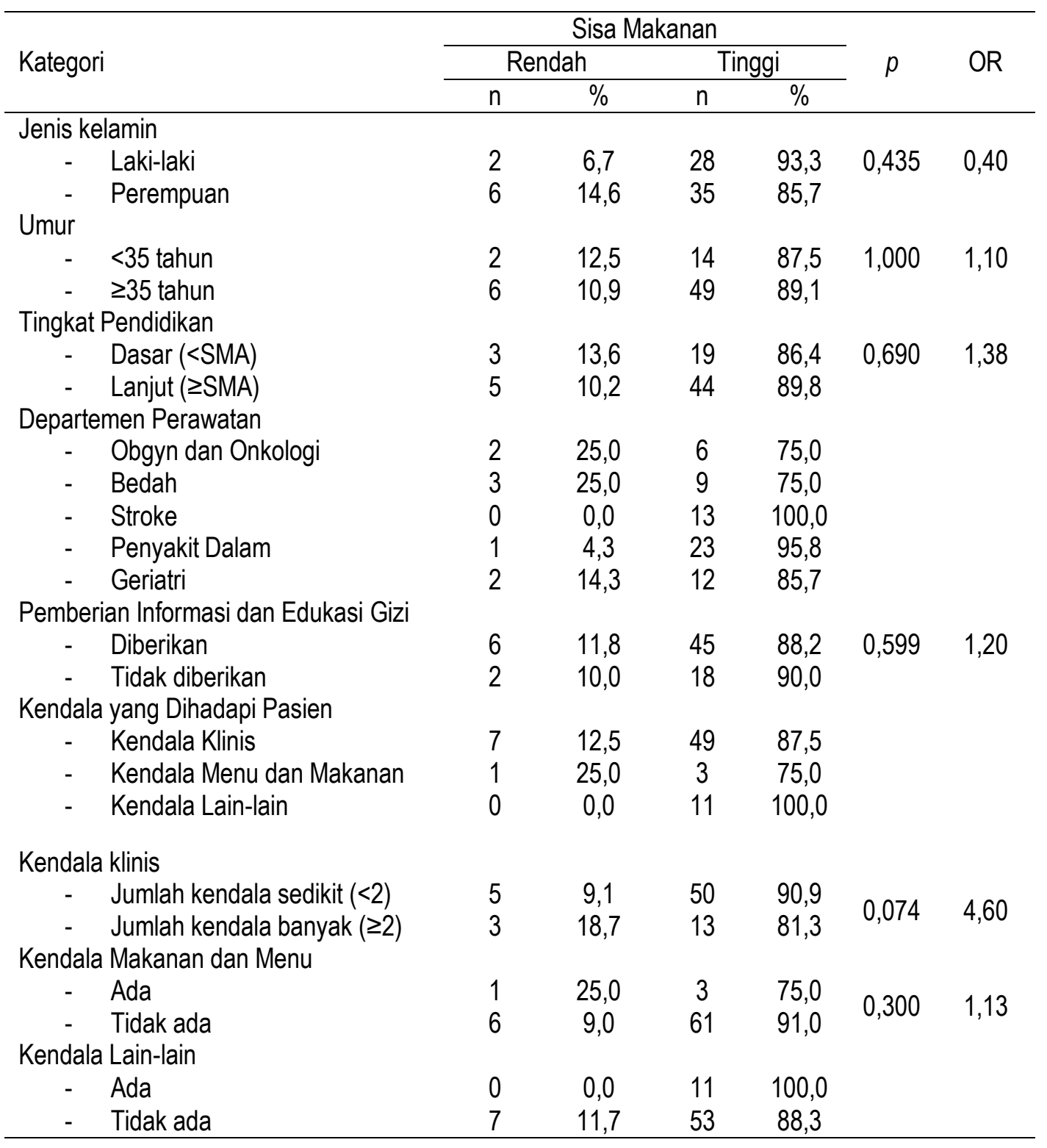

\section{BAHASAN}

\section{Karakteristik subjek}

Berdasarkan Tabel 1 dapat dilihat bahwa jenis kelamin subjek sebagian besar adalah perempuan. Dari total 71 responden, terdapat 57,7 persen responden perempuan. Berdasarkan hasil penelitian Tanuwijaya dkk., pada tahun 2018 di RS Universitas Muhammadiyah Malang, perbedaan jenis kelamin memengaruhi tindakan pasien tidak secara langsung dalam menyisakan makanan. ${ }^{11}$
Namun, kondisi khusus yang memengaruhi nafsu makan pasien perempuan juga ditemukan sehingga jenis kelamin dapat menjadi faktor yang memengaruhi pilihan jenis makanan..$^{13}$

Penggolongan umur dengan batas 35 tahun didasarkan pada penelitian terdahulu yang menggunakan pengelompokkan umur yang serupa ${ }^{14}$ dengan hasil yang didapatkan sebagian besar subjek berumur $\geq 35$ tahun. Proporsi yang lebih besar ini berhubungan juga dengan keadaan fisik pasien yang berhubungan 
erat dengan keinginan serta kemampuan pasien dalam mengkonsumsi makanan. ${ }^{4}$

Berdasarkan tingkat pendidikan, sebagian besar subjek memiliki pendidikan lanjut. Menurut UU No. 20 Tahun 2003 tentang Sistem Pendidikan Nasional, tingkat pendidikan subjek ini termasuk dalam jenjang pendidikan formal menengah (SMA dan/atau sederajat) dan tinggi (Diploma/Sarjana/Magister). ${ }^{15}$

Penggolongan karakteristik departemen perawatan didasarkan pada penggolongan yang digunakan di Gedung A. Dari Tabel 1 dapat diketahui bahwa sebagian besar subjek dirawat di Departemen Penyakit Dalam (33,8\%). Departemen Perawatan Obsgin dan Onkologi memiliki jumlah subjek paling sedikit, yaitu 11,3 persen.

Sisa makanan, jenis sisa makanan, dan jalur pemberian

Berdasarkan Tabel 2, sisa makanan cair dalam kategori tinggi (>20\%) mencapai 88,7 persen. Sisa makanan adalah jumlah makanan yang tidak habis dikonsumsi setelah makanan disajikan(16). Sisa makanan yang tidak termakan oleh pasien memiliki standar sebesar $\leq 20 \%$ yang dijadikan sebagai salah satu dari Standar Pelayanan Minimal Rumah Sakit di bidang gizi yang diatur dalam Menteri Kesehatan Republik Indonesia No. 129/Menkes/SK/II/2008(5).

Nafsu makan menjadi faktor utamanya, tetapi faktor lain yang menyebabkan terjadinya sisa makanan juga ada, seperti faktor yang berasal dari luar pasien atau faktor eksternal dan faktor yang berasal dari dalam pasien atau faktor internal. ${ }^{4}$ Terdapat dua jenis makanan cair yang digunakan, yaitu Formula Rumah Sakit dan Formula Komersial. Formula Rumah Sakit memiliki berbagai macam indikasi pemberian yang disesuaikan dengan indikasi penyakitnya. ${ }^{12}$ Formula Rumah Sakit rendah laktosa atau dinamakan Low Lactose Milk (LLM) merupakan jenis makanan cair yang memiliki kandungan laktosa yang rendah yang ditujukan untuk pasien yang tidak tahan terhadap laktosa (lactose intolerant) $^{12}$ sehingga relative aman untuk diberikan kepada pasien. Formula Rumah Sakit lainnya, yaitu Cair Jernih dan Blenderize termasuk dalam kategori tiga makanan cair yang sebagian besar bersisa. Makanan Cair DM atau makanan cair yang dikhususkan untuk penderita Diabetes Mellitus dan makanan cair
TPS atau makanan cair tanpa susu yang terbuat dari kacang hijau untuk pasien yang tidak tahan protein susu ${ }^{12}$ juga termasuk dalam Formula Rumah Sakit. Makanan cair formula komersil berada pada urutan terendah pada jenis makanan cair yang bersisa. Makanan cair formula komersil yang bersisa adalah Diabetasol, Peptisol, dan Proten. Jumlah makanan cair yang bersisa ini berhubungan dengan jumlah pemberian makanan cair karena makanan cair LLM lebih banyak diberikan.

Berdasarkan jalur pemberian makanan cair, sebagian besar subjek mendapat makanan cair melalui oral sehingga pasien dapat meminum sendiri makanan cair. Oleh karena itu, pasien memiliki kebebasan yang lebih dibanding pasien yang menggunakan jalur selang untuk mengonsumsi makanan cairnya. Sedangkan pada pasien yang menggunakan jalur pemberian selang harus mengandalkan bantuan orang lain untuk mengonsumsi makanan cair. Walaupun tidak ada masalah dengan rasa dan aroma,tetapi masih terdapat sisa makanan cair pada jalur pemberian lewat selang. Kemungkinan hal ini disebabkan karena faktor eksternal, antara lain ketelatenan dalam pemberian makanan dan kesabaran pasien

\section{Pemberian informasi dan edukasi gizi dan kendala yang dihadapi pasien}

Dari Tabel 3, diketahui bahwa sebagian besar subjek menerima informasi dan edukasi gizi dari dietisien. Meskipun demikian, masih terdapat subjek yang mengaku belum mendapat informasi dan edukasi gizi.

Pemberian informasi kesehatan adalah usaha atau kegiatan yang dilakukan dalam rangka memberikan informasi kesehatan terhadap masalah kesehatan pasien yang belum diketahui oleh pasien dan keluarganya, sedangkan hal tersebut perlu diketahui untuk membantu dan mendukung penatalaksanaan medis serta melibatkan pasien dan keluarga dalam penatalaksanaan pelayanan kesehatan di rumah sakit. ${ }^{17}$

Pemberian informasi dan edukasi gizi merupakan bagian dari pelayanan gizi rawat inap. ${ }^{1}$ Informasi dan edukasi gizi yang ditanyakan dalam penelitian ini adalah persepsi pasien atau pendamping terhadap dietisien dalam memberikan informasi dan edukasi terkait penjelasan rencana asuhan gizi yang dilakukan seperti makanan yang diberikan di 
rumah sakit, penjelasan akan pentingnya makanan tersebut, dan lainnya. Pemberian informasi dan edukasi gizi tidak terbatas diberikan oleh dietisien tetapi juga oleh perawat dan dokter.

Berdasarkan kendala yang dihadapi pasien dalam mengonsumsi makanan cair, kendala klinis menempati tempat teratas disusul oleh kendala lainnya dan kendala makanan dan menu. Kendala klinis termasuk dalam faktor internal dan kendala makanan dan menu serta kendala lain-lain termasuk dalam faktor eksternal. Kendala klinis yang ditemukan antara lain, rasa begah, kenyang, mual, diare, kembung, ganti diet, muntah, sakit perut, dan tidak bisa minum banyak. Kendala klinis, seperti mual, dapat dipengaruhi juga oleh obat yang dikonsumsi. Selain itu, keadaan dan kebiasaan subjek seperti tidak bisa minum banyak juga turut memengaruhi. Pergantian diet termasuk dalam kendala klinis karena berhubungan dengan modifikasi tekstur diet yang mengikuti keadaan pasien. Kendala diare dialami oleh pasien yang menggunakan selang NGT dan diduga terjadi karena tidak cocok dengan formula makanan cair yang diberikan.

Dalam kategori kendala menu dan makanan, subjek menyatakan bahwa makanan cair tidak dihabiskan karena tidak menyukai makanan cair yang diberikan. Pasien tidak menyukai pilihan makanan cair yang diberikan sehingga memengaruhi terjadinya sisa makanan cair. Penggantian cara pemberian makanan cair secara oral ke pemberian lewat selang dapat dilakukan setelah ada instruksi dokter

Kendala lain yang ditemukan adalah lupa dan ketiduran. Selain itu, perlu adanya peningkatan peran dietisien dalam memberikan edukasi kepada anggota keluarga terkait preskripsi diet yang diberikan antara lain, jenis makanan cair yang diberikan, volume makanan cair dalam sekali pemberian, dan frekuensi pemberiannya. Kendala lain makanan cair bersisa adalah pasien telah tidur saat makanan cair datang, khususnya pada pemberian makanan cair pukul 21.00 WIB dan saat pasien terbangun makanan cair sudah mencapai batas kadaluarsanya sehingga tidak dapat dikonsumsi lagi. Seorang pasien juga lupa untuk meminum makanan cair sehingga makanan cair bersisa.

\section{Hubungan Sisa Makanan Cair dengan Karakteristik, Pemberian Informasi, dan Edukasi Gizi, Kendala yang Dihadapi Pasien}

Dari Tabel 4 diketahui bahwa subjek yang menyisakan makanan cair dalam kategori tinggi $(>20 \%)$ sebagian besar berjenis kelamin lakilaki. Hal tersebut sejalan dengan penelitian Usdeka Muliani di RSUD Dr. H. Abdul Moeloek, Provinsi Lampung tahun 2011 bahwa jenis kelamin laki-laki lebih banyak menyisakan makanan saring dalam kategori sisa kurang baik. ${ }^{18}$ Nilai $p$ diperoleh sebesar 0,435 sehingga dapat disimpulkan bahwa tidak ada hubungan yang signifikan antara jenis kelamin pasien dengan sisa makanan cair pasien. Dari nilai OR sebesar 0,4 dapat dikatakan pasien laki-laki berpeluang menyisakan makanan cair 0,4 kali dibandingkan dengan pasien perempuan. Hal ini serupa dengan hasil penelitian Yasya Nashua pada tahun 2018 di RS Bhakti Asih Brebes yang menemukan bahwa tidak terdapat hubungan antara sisa makanan biasa berdasarkan jenis kelamin. ${ }^{8}$ Pernyataan tersebut juga didukung dalam penelitian Putri Ronitawati pada tahun 2017 di RSUD Koja, Jakarta mengenai diet biasa dan lunak..$^{19}$ Jika dibandingkan dengan sisa makana saring, penelitian Usdeka Muliani di RSUD Dr. H. Abdul Moeloek tahun 2011 mengungkapkan hal yang sama. ${ }^{18}$ Demikian juga dalam penelitian Lestari dkk., di RS Holistik tahun 2016 yang hanya khusus membahas sisa makanan pokok. ${ }^{20}$

Berdasarkan kelompok umur, dapat dilihat bahwa subjek yang menyisakan makanan cair dalam kategori tidak terpenuhi sebagian besar berumur $\geq 35$ tahun $(89,1 \%)$. Beberapa penelitian lainnya juga membuktikan bahwa kelompok umur yang lebih tua cenderung banyak menyisakan makanannya, antara lain penelitian di RS Djatiroto Lumajang pada tahun 2015 tentang sisa makanan lunak dan biasa, kategori umur 50-64 tahun mendominasi sisa makanan yang lebih banyak..$^{21}$ Hasil yang sama juga ditemukan dalam penelitian yang dilakukan oleh Wirasamadi, et al. di RSUP Sanglah Denpasar tahun 2015 mengenai sisa makanan biasa. ${ }^{22}$ Khairun Nida et al. dalam penelitian tentang sisa makanan biasa di RS Jiwa Sambang Lihum yang membagi kelompok umur menjadi $<35$ tahun dan $\geq 35$ tahun, menunjukkan bahwa kelompok umur $\geq 35$ tahun memiliki sisa lebih tinggi. ${ }^{14}$ 
Nilai $p$ diketahui lebih besar dari 0,05 sehingga dapat dikatakan bahwa tidak ada hubungan yang signifikan antara umur dan sisa makanan cair. Hal sejalan juga dengan penelitian Putri Ronitawati, dkk, di RSUD Koja Jakarta Utara yang menemukan hubungan yang tidak signifikan antara umur dan sisa makanan biasa dan lunak. ${ }^{19}$ Dalam penelitian Ariefuddin dkk., di RSUD Gunung Jati Cirebon mengenai sisa makanan lunak pada tahun 2009 disebutkan juga bahwa tidak adanya hubungan. ${ }^{23}$ Penelitian oleh Lestari dkk., di RS Holistik tahun 2016 mengungkapkan hal yang sama mengenai sisa makanan pokok. ${ }^{20}$ Demikian juga dalam penelitian Usdeka Muliani yang berfokus pada sisa makanan saring di RSUD Dr. H. Abdul Moeloek tahun 2011.18 Nilai OR yang diperoleh adalah 1,1 yang berarti pasien yang berumur $\geq 35$ tahun berpeluang 1,1 kali untuk menyisakan makanan cair dibandingkan pasien yang berumur $<35$ tahun

Jika dilihat berdasarkan tingkat pendidikan, diketahui bahwa kejadian sisa makanan cair tinggi atau lebih dari standar (>20\%) sebagian besar dilakukan oleh subjek dengan pendidikan terakhir minimal SMA $(89,8 \%)$ dibandingkan dengan subjek dengan pendidikan terakhir di bawah SMA. Dari hasil hitung statistik disimpulkan bahwa tidak ada hubungan antara tingkat pendidikan dan sisa makanan cair. Diperolehnya nilai OR sebesar 1,38 sehingga dapat dikatakan bahwa pasien yang berpendidikan lebih rendah dari SMA berpeluang menyisakan makanan cair 1,4 kali dibandingkan pasien yang berpendidikan minimal SMA. Hasil penelitian ini di tunjang oleh beberapa hasil penelitian lain. Penelitian yang dilakukan Indah Yulianti di Gresik mengenai sisa makanan biasa, lunak, dan saring pada tahun 2013 yang menemukan bahwa tidak terdapat hubungan yang signifikan antara sisa makanan dengan tingkat pendidikan. ${ }^{24}$ Penelitian di RS Bhakti Asih Brebes oleh Yasya Nashua tahun 2018 mengenai sisa makanan biasa juga berpendapat demikian. ${ }^{8}$ Demikian juga dengan hasil penelitian Nida dkk., di RSJ Sambang Lihum tahun 2011 yang juga berfokus pada sisa makan biasa. ${ }^{14}$

Subjek yang menyisakan makanan cair kategori tinggi sebagian besar tidak diberikan informasi dan edukasi gizi. Pemberian edukasi dan informasi gizi merupakan bagian dari intervensi gizi yang diberikan kepada pasien dewasa/orang tua pendamping/penunggu pasien anak selama dirawat atau sebelum pulang. Hasil analisis statistik menunjukkan tidak ada hubungan antara pemberian edukasi dan informasi gizi dengan sisa makanan cair. Diperoleh nilai OR 1,2 yang menunjukkan pasien yang tidak diberikan informasi dan edukasi gizi berpeluang 1,2 kali untuk menyisakan makanan cair dibandingkan pasien yang menerima informasi dan edukasi gizi. Hal ini bertolak belakang dengan penelitian di RSI Klaten pada pasien diabetes melitus yang menerima makanan biasa yang-menunjukkan bahwa terdapat perubahan sisa makan siang sebelum dan sesudah mendapat konseling gizi. ${ }^{9}$ Hal tersebut dapat terjadi karena jenis subjek pada penelitian di RSI Klaten lebih homogen yang hanya mencakup pasien dengan diagnose penyakit Diabetes Mellitus, sedangkan dalam penelitian ini subjek memiliki beragam diagnosa penyakit.

Dari kendala yang dihadapi subjek dapat diketahui bahwa subjek yang menyisakan sisa makanan cair dalam kategori tidak terpenuhi sebagian besar menghadapi kendala lain-lain $(100 \%)$. Kendala lain-lain termasuk pemberian makanan cair dibatasi oleh keluarga, lupa, ataupun ketiduran. Pada variable kendala klinis, diidentifikasi bahwa subjek yang menyisakan makanan cair dalam kategori tinggi sebagian besar memiliki kendala klinis yang sedikit. Kendala klinis yang sedikit ditentukan berdasarkan jumlah kendala klinis yang dihadapi oleh pasien <2 kendala. Kendala klinis yang ditemukan antara lain, rasa begah, kenyang, mual, diare, kembung, ganti diet, muntah, sakit perut, dan tidak bisa minum banyak. Hasil uji statistik menunjukkan tidak ada hubungan antara kendala klinis dengan sisa makanan cair. Hal ini bertolak belakang dengan penelitian Tanuwijaya dkk., tahun 2018 di RS Muhammadiyah Malang tentang sisa makanan biasa dan lunak yang menyatakan bahwa faktor internal pasien yang dominan memengaruhi pasien menyisakan makanan di rumah sakit salah satunya adalah kondisi fisik. ${ }^{11}$ Perbedaan itu dapat terjadi karena adanya perbedaan metode yang dilakukan, yaitu pendekatan kualitatif dengan metode wawancara mendalam yang semi terstruktur dengan jumlah subjek sebanyak 6 orang pada penelitian tersebut. Nilai Odd Rasio sebesar 4,6 artinya pasien dengan kendala klinis banyak 
( $\geq 2$ kendala) berpeluang 4,6 kali untuk menyisakan makanan cair dibandingkan pasien dengan kendala klinis yang sedikit ( $<2$ kendala). Pada peneltian yang dilakukan oleh Candradewi dkk., di RS Sanglah ${ }^{25}$, masih ada responden yang menyisakan makanan cair karena mengalami gangguan pencernaan seperti mual dan muntah yang bisa menyebabkan kehilangan nafsu makan dan tidak mampu menghabiskan makanannya.

Dari 4 subjek penelitian, terdapat 3 subjek (75\%) yang memiliki kendala makanan dan menu. Hasil analisis statistik disimpulkan bahwa kendala makanan dan menu tidak memiliki hubungan yang signifikan dengan sisa makanan cair. Temuan tersebut sejalan dengan penelitian di Surakarta yang menyatakan bahwa tidak ada hubungan antara cita rasa makanan dengan sisa makanan di rumah sakit. ${ }^{26}$ Demikian halnya dengan penelitian Aula di RS Haji Jakarta mengenai sisa makanan biasa dan lunak yang menunjukkan cita rasa tidak mempengaruhi terjadinya sisa makanan pada pasien. ${ }^{27}$ Penelitian tentang sisa makanan saring oleh Usdeka Muliani di RSUD Dr. H. Abdul Moeloek tahun 2011 mengemukakan hal serupa. ${ }^{18}$ Cita rasa makanan termasuk dalam masalah makanan dan menu yang dimiliki oleh 4 orang pasien yang menyatakan bahwa makanan cair bersisa karena mereka tidak menyukai rasa makanan cair yang diberikan yang dalam hal ini termasuk dalam mutu makanan. Nilai Odd Rasio, sebesar 1,13 sehingga dapat dikatakan pasien yang memiliki kendala makanan dan menu berpeluang 1,13 kali untuk menyisakan makanan cair.

Keterbatasan penelitian adalah tidak dilakukannya analisis multivariat untuk melihat variabel mana yang paling berkontribusi terhadap sisa makanan. Selain itu hasil penelitian tentang sisa makanan cair masih sangat jarang ditemukan.

\section{SIMPULAN DAN SARAN}

\section{Simpulan}

Sisa makanan cair di RSUPN Dr. Cipto Mangunkusumo yang termasuk dalam kategori tinggi (>20\%). Sisa makanan cair disebabkan oleh jenis penyakit, seperti stroke dan penyakit dalam, kendala klinis seperti mual, muntah, diare, kembung, kenyang, kurang nafsu makan, mulas, dan perubahan diet. Meskipun tidak ditemukan hubungan yang signifikan antara variable bebas dan terikat, didapatkan kecenderungan terjadinya sisa makanan cair tinggi ( $>20 \%$ ) pada pasien berjenis kelamin lakilaki, pasien berumur $\geq 35$ tahun, pasien dengan tingkat pendidikan minimal SMA, pasien yang tidak diberikan informasi dan edukasi gizi, dan pasien dengan kendala lain-lain.

\section{Saran}

Disarankan untuk dilakukan penelitian lanjutan tentang kepuasan pasien terhadap makanan cair yang diberikan sebagai upaya untuk meningkatkan asupan makanan cair.

\section{UCAPAN TERIMA KASIH}

Terima kasih kepada Instalasi Gizi RSUPN Dr. Cipto Mangunkusumo, khususnya Pelayanan Gizi Gedung A, atas bimbingan dan dukungannya dalam penelitian ini.

\section{RUJUKAN}

1. Kementerian Kesehatan Republik Indonesia R. Pedoman Pelayanan Gizi Rumah Sakit. Jakarta: Kementrian Kesehatan RI; 2013. 163 p.

2. Almatsier S. Persepsi Pasien terhadap Makanan di Rumah Sakit. J Gizi Indones. 1992;2:87-96.

3. Bulson $\mathrm{H}$, Pickering J, Henderson A, Shape N. Managing NHSS Food Waste. Scotland; 2012.

4. Moehyi. Penyelenggaraan Makanan Institusi dan Jasa Boga. Jakarta: Bhatara; 1992.

5. Kementrian Kesehatan RI R. Menteri Kesehatan RI No. 129/Menkes/SK/II/2008 tentang Standar Pelayanan Minimal Rumah Sakit. In 2008.

6. Sembiring E. Faktor-faktor yang Berhubungan dengan Adanya Sisa Makanan Biasa pada Pasien Rawat Inap di Kelas III RS Pringadi Medan. Universitas Sumatera Utara; 2014.

7. Salman $Y$, Saputri R, Ridha MR. Faktor- 
Faktor Yang Berhubungan denganTerjadinya Sisa Makanan Pasien Diabetes Mellitus Di Rumah Sakit Umum Daerah Dr. H. Moch. Ansari Saleh Banjarmasin. JurkessiaJ. 2014;IV(6):1-6.

8. Nashua $Y$. Analisis Hubungan Kepuasan Pasien Rawat Inap dengan Sisa Makanan dan Biayanya di RS Bhakti Asih Brebes Tahun 2018. Institut Pertanian Bogor; 2018.

9. Silawati ET. Efektivitas Konseling Gizi terhadap Perubahan Sisa Makan Siang Pada Pasien Diabeter Mellitus Rawat Inap di RSI Klaten. Universitas Muhammadiyah Surakarta; 2017.

10. Ngatmira A. Penetapan standar porsi diet berdasarkan sisa makanan pasien bedah di RSUPN DR Ciptomangunkusumo tahun $2013=$ The determination of standard diet portions based on surgery patients waste plate DR Ciptomangunkusumo National Center General Hospital in 2013. Universitas Indonesia; 2013.

11. Tanuwijaya LK, Sembiring LG, Dini CY. Sisa Makanan Pasien Rawat Inap: Analisis Kualitatif. Indones J Hum Nutr. 2018;5(1):51-61.

12. Almatsier S. Penuntun Diet. Jakarta: Gramedia Pustaka Utama; 2004.

13. Wansink B, Cheney $M$, Chan $N$. Exploring Comfort Food Preferences Across Age and Gender. Physiol Behav. 2003;79(4):39-47.

14. Nida K, Efendi R, Norhasanah. Faktorfaktor yang Berhubungan dengan Sisa Makanan Pasien Rawat Inap di Rumah Sakit Jiwa Sambang Lihum. Jurkessia. 2011;2(1):1-8.

15. Nasional USP. Undang-Undang RI No. 20 Tahun 2003 Sistem Pendidikan Nasional. 2003.

16. Williams PG, Walton K. Plate waste in hospitals and strategies for change. Univ Wollongong. 2011;6(6).

17. Penulis T. Panduan Pemberian Informasi dan Edukasi di RS Sari Asih
Karawaci. Tangerang: RS Sari Asih Karawaci;

18. Muliani U. Faktor-Faktor yang Berhubunga dengan Sisa Makanan Saring Pasien Rawat Inap. J Keperawatan. 2013;IX(1):31-6.

19. Ronitawati P, Puspita M, Citra K, Gizi PS, Kesehatan FI, Unggul UE, et al. Faktor-faktor yang Berhubungan dengan Sisa Makanan di RSU Daerah Koja Jakarta Utara Tahun 2017. Heal Sci Growth J. 2017;3(1):57-76.

20. Lestari YN, Torina DT, Gizi SI, Tinggi S, Kesehatan I, Purwakarta $\mathrm{H}$, et al. Hubungan Perubahan Standar Porsi Makan dengan Sisa Makanan Pasien Rumah Sakit Holistik Tahun 2016. J Gizi Indones. 2017;40(1):1-8.

21. Dewi LS. Faktor-faktor yang Berhubungan dengan Sisa Makanan pada Pasien Rawat Inap di Rumah Sakit Djtiroto Lumajang. Universitas Jember; 2015.

22. Wirasamadi NLP, Adhi KT, Weta IW, Wirasamadi NLP, Adhi KT, Weta IW, et al. Analisis Sisa Makanan Pasien Rawat Inap di RSUP Sanglah Denpasar Provinsi Bali. Public Heal Prev Med. 2015;3(1):88-95.

23. Ariefuddin MA, Kuntjoro $T$, Prawiningdyah Y. Analisis Sisa Makanan Lunak Rumah Sakit pada Penyelenggaraan Makanan dengan Sistem Outsourcing di RSUD Gunung Jati Cirebon. J Gizi Klin Indones. 2009;5(3):133-42.

24. Yulianti I. Sisa Makanan dan Kepuasan pada Pasien Rawat Inap Kelas III di Rumah Sakit Swasta Gresik Jawa Timur. Bogor Agricultural University. Intitut Pertanian Bogor; 2013.

25. Candradewi A, Masitah R, Sulityadewi N. Hubungan Ketepatan Waktu Konsumsi terhadap Sisa Makanan Cair Penuh Pasien Dewasa di RSUP Sanglah Denpasar. Semin IIm Nas Teknol Sains, dan Hum. 2019;2.

26. Nafies DA. Hubungan Cita Rasa Makanan dan Konsumsi Makanan dari 
Luar RS dengan Sisa Makanan Biasa pada Pasien di RS Orthopedi Prof. DR.

R. Soeharso Surakarta. Universitas Muhammadiiyah Surakarta; 2016.

27. Aula L. Faktor-Faktor Yang
Berhubungan Dengan Terjadinya Sisa Makanan Pada Pasien Rawat Inap Di Rumah Sakit Haji Jakarta. repository. uinjkt.ac.id. Universitas Islam Negeri Jakarta; 2011. 